seriously disputes the clanger of consuming food even in an early stage of decomposition and I assert without fear of contradiction that in the conditions under which the poor live in our large cities their food is certain to undergo rapid decomposition in hot weather unless preservatives are employed. I am, Sirs, yours faithfully,

Thos. R. Bradshaw, B.A., M.D. Dul., F.R.C.P. Lond., August 21st, 1904 .

\section{THE AMALGAMATION OF THE LONDON ORTHOPÆDIC HOSPITALS.}

To the Editors of THE LANCET.

SIBS,-As one of the governors of the City Orthopædic Hospital, by whose vote it was decided to refuse to incorporate with the two other orthopædic hospitals, I think it only right to state our reasons for this refusal and I think that when they have been considered the action of the Hospital Sunday Fund committee in refusing the usual grant to this most deserving institution for the purpose of coercing them will appear most unjustifiable. The City Orthopædic Hospital is worked at very small cost for administration and nearly the whole of the money subscribed goes to the patients. It is on a freehold site in one of the most accessible spots for the poorer inhabitants of London; it can be reached by a $1 d$. omnibus fare or $1 d$. railway fare from all the poorer districts of London. It treats a class of disease to which the poor are particularly subject.

It was proposed to amalgamate the three orthopoedic hospitals and erect a large building at immense cost on a leasehold site at the West End of London, thus taking it too far away from the poor districts and spending a very large sum on bricks and mortar, which is at present available for relieving the very great sufferings of the people. The proceeding would increase the administrative expenses much out of pro portion to the good to be derived from the amalgamation. I think that pressure must have been brought to bear in some way to prevent the usual grant, as I cannot understand anyone who has gone into the matter fairly refusing funds to so deserving a charity as ours. I feel sure that it is only necessary for anyone to visit this institution, which is situated in Hatton-garden, to see how carefully the committee have husbanded their resources and the very kind way in which the poor little sufferers are treated to insure plenty of donations and subscriptions to carry on this most humane work without the aid of the Hospital Sunday Fund committee. I am, Sirs, yours faithfully, Sydenham, August 18th, 1904

JAMES A. PHILLIPS

\section{DOES BOILING IMPROVE THE KEEPING PROPERTIES OF MILK ?}

\section{To the Editors of THE LANCET.}

SIRS,- To most practitioners I apprehend that the boiling of milk at this season of the year for the purpose of "keeping it sweet" is an axiom of practice which I had always suspected admitted of no doubt. Recently, however, a friend of mine, a bacteriologist, vigorously attacked $\mathrm{my}$ instruction to boil milk. "Why," he asked, "do you boil the milk?" I replied : first, at this season of the year, to prerent souring and decomposition ; secondly, to destroy pathosenic germs; thirdly, it is said to make the milk more digestible; and lastly, if the child has diarrhoa it is to help to constipate the child.

Now, does boiling the milk have a good effect on its keeping properties, especially under the contaminating influences of hot weather? I have always thought so, but my friend roundly declares that it is absolutely harmful, and for these reasons. First, he says that I confuse souring with decomposition or putrefaction. The one is due to lactic acid fermentation, the other to changes set up by dirt organisms or the organism of putrefaction, two altogether different processes and mutually antagonistic. When we set about boiling the milk we destroy the lactic acid organisms, which die, say, at or about a temperature of $180^{\circ}$, while the dirt organisms, which are spore bearing, are at that temperature quite unharmed. What, then, is the result? The milk is certainly, by the act of heating, prevented from souring and to outward appearances keeps good, but if it is kept for a few hoursprobably all night-at the temperature of the room or flat, say, at or above $80^{\circ}$, putrefaction has full opportunity of taking place under the most advantageous circumstances and toxic agents are developed in the milk which are much more pernicious than the souring. Souring is such a visible process that it is unmistakable, but, on the other hand, these invisible toxic agents give no evidence of their existence, either in taste or smell (possibly in some instances the milk may become slightly sweeter), by which they can be recognised and these products, my friend declares, are often the deleterious substances which give rise to the fearfully sudden collapse in some infants about whose feeding the mothers have been more than usually careful by taking pains to boil the milk before using it. My bacteriological friend goes so far as to say that sour milk in itself is not harmful! This statement reminds me that in my native county basins of sour milk were eaten with avidity, mixed with the coarse brown sugar of olden days or with treacle, by the farm hands on many of the farms I have stayed at in the days of my youth. He urges strongly that the lactic acid fermentation is actually nature's own means of preventing the process of putrefaction owing to the fact that most of the putrefactive germs require an alkaline or neutral medium for their development and that this is impossible as long as the lactic acid germs are allowed to exert their influence, but directly we set about killing these by boiling we immediately give the putrefactive germs full scope to develop and this by the very means which we in our ignorance of nature's processes had hoped would be effective in the opposite direction.

I am, Sirs, yours faithfully,

RICHARD BEVAN, L.R.C.P. Lond., D.P.H.

Kensington, August 5th, 1904.

** Boiling must obviously delay decomposition by destroying germs, but the effect, of course, can only be temporary if the milk is afterwards allowed to cool down exposed to the air. The destruction of pathogenic organisms is more likely to be effectually done by heating than by waiting for the development of lactic acid.-ED. L.

\section{PREVENTION OF PUERPERAL FEVER.}

\section{To the Editors of THE LANCET.}

Sins,-The paper written by Professor Byers on this subject leads one to think furiously. For years past the members of the medical profession have listened to very tall talk from obstetricians and we are still to listen. A little incident occurred at Oxford at a discussion in the obstetrical section upon the treatment of accidental hæmorrhage which I trust will tend to make our obstetrical professors also consider. Professor Galabin informed his. audience that he had been in favour of the treatment of vaginal plugging and was so at that moment; that he advocated this method in early editions of his little book for students but that he had omitted to do so in latereditions because he found that his students complained that they failed to pass examinations for stating that this was the method which in practice they would adopt. The method in question, I may perhaps be allowed to state, is that which was taught by those great authorities, Dr. Rigby and Dr. Matthews Duncan. It was strange to find that the reintroduction of the method has been necessary.

I shall be glad to hear in what proportion of the reports written by medical officers of health annually is attention called to excessive puerperal mortality. If any accurate appreciation of the work performed by the ordinary working accoucheurs of Great Britain is undertaken some attention must be paid to the conditions of life which obtain in those parts of the country where puerperal mortality is high. So far as my limited lights allow me to form an opinion, the prevalence of puerperal sepsis-or indeed surgical sepsis-depends first upon the sound grounding of students in first principles by the teacher; secondly, upon the personal equation of the student; and thirdly, upon the general conditions under which the student, when he becomes a practitioner, is placed. Looking over the period since Hughes Bennet introduced the speculum and passing in review the various teaching concerning the so-called congestions and ulcerations of the cervix, concerning the use of pessaries, concerning operative interferences with women for disease not connected with pregnancy, and concerning operative interference with the various complications connected with pregnancy and childbirth, it is impossible to assert that the teachers of the third compulsory branch of professional 